\title{
PENGARUH POSITIF FORMULA GARAM MULTIMINERAL (MM) PADA PENDERITA HIPERTENSI
}

\author{
Tejasari ${ }^{1}$, Antok Suwardiyanto ${ }^{2}$, Farida Wahyu Ningtyas ${ }^{3}$ \\ 1 Jurusan Teknologi Hasil Pertanian, FTP, Universitas Jember \\ 2Jurusan Kimia Anorganik, FMIPA, Universitas Jember \\ 3Bagian Gizi Masyarakat, FKM, Universitas Jember \\ tejaharto@yahoo.com
}

\section{ABSTRAK}

Data survei kesehatan rumah tangga (SKRT) menunjukkan prevalensi hipertensi terus meningkat, saat ini di atas 17 persen. Selain tinggi asupan $\mathrm{Na}$, hipertensi disebabkan juga oleh ketidakseimbangan asupan mineral pengatur tekanan darah, ketidaktersediaan pangan tinggi mineral esensial, dan terbatasnya pengetahuan pengendalian hipertensi. Tujuan penelitian ini adalah mengevaluasi pengaruh positif konsumsi garam multimineral (MM) fungsional oleh penyandang hipertensi, yang dirancang sebagai double blind randomized control trial, dan dibuktikan secara klinis. Tiga formula garam MM ditentukan berdasarkan perhitungan kebutuhan mineral ( $\mathrm{Ca}, \mathrm{Mg}$, dan $\mathrm{K})$, dan diformulasi dengan dry homogenized technique. Kadar mineral (elektrolit) darah subjek dianalis dengan metoda Atomic Absorption Spectrophotometry (AAS). Hasil uji mutu menunjukkan bahwa garam MM bersifat larut sempurna dalam air dingin, tidak menimbulkan kekeruhan, dan tidak berubah warna dari warna garam. Garam MM dengan nilai rerata derajat putih 72,4 dan kadar air rerata garam MM sebesar 1 persen masih disukai warna (nilai=3.2) dan rasanya (nilai=2,89). Uji statistik membuktikan bahwa konsumsi garam MM sebanyak 2000 $\mathrm{mg}$ x 3 kali makan dalam sehari $(6000 \mathrm{mg})$ selama 30 hari oleh penderita hipertensi secara nyata menurunkan tekanan darah sistolik-TDS (nilai chi square $=27,381$ dengan nilai Asymp. Sig $0,000<\alpha=0,05$ ) dan tekanan darah diastolic-TDD (nilai chi square $=38,483$ dengan nilai Asymp. Sig $0,000<\alpha=0,05$ ).

Kata kunci: pengaruh positif, garam multimineral (MM), hipertensi

\section{ABSTRACT}

\section{THE POSITIVE EFFECT OF MULTIMINERAL SALT IN HYPERTENSION PATIENTS}

Sodium salt contains especially sodium and chloride minerals. In sufficient amount, sodium salt intake is needed for nerve stimulation and muscle contraction. However, over salt consumption in certain period was revealed scientifically associated to hypertension, heart disease, and stroke. Social phenomena shows there is increasingly high sodium food consumption pattern especially comes from fast, canned, and preserved food. This food habit creates imbalance essential intake of blood pressure regulating minerals, and consequently brings about hypertension, heart disease, diabetes mellitus, and stroke. Household health survey showed that hypertension prevalence had been increasing continously. Besides imballance mineral intake, several hypertension are caused by limited availability of food high in the minerals and limited knowledge of blood pressure control. The main aim of this study is to evaluate health effect of multimineral (MM) salt consumed by hypertension's subject, performed by double blind randomized control trial and clinically approved. Three MM salt formulas were determined by mineral $(\mathrm{Ca}, \mathrm{Mg}$, and $\mathrm{K})$ requirement calculations, and were formulated by dry homogenized technique. Blood minerals (electrolyte) of the subject were analyzed by Atomic Absorption Spectrophotometer (AAS) method. Quality analysis result showed that MM salt was soluble in cold water, not clear (cloudy), and permanently had white color $(72,4)$. Statistical analysis confirmed that the MM functional salt in amount of $2000 \mathrm{mg}$ three times a day $(6000 \mathrm{mg})$ and had been consumed for 30 days by hypertension subjects significantly decreased their systolic blood pressure or $\operatorname{SBP}\left(1,3 \% ; \chi^{2}=27,381\right.$ with $\left.p<0,05\right)$ and diastolic blood pressure or $\operatorname{DBP}\left(6,4 \% ; X^{2}=38,483\right.$ with $\left.p<0,05\right)$.

Keywords: positive effect, multimineral salt, hypertension

\section{PENDAHULUAN}

$\mathrm{H}$ ipertensi difahami sebagai suatu kondisi pola kenaikan tekanan darah arteri yang terus menerus, dengan tekanan sistolik dan diastolik lebih besar dari nilai normal $(>120 / 80 \mathrm{mgHg} / \mathrm{dL})$. Kenaikan tekanan darah tidak normal disebabkan, antara lain, oleh ketidakseimbangan kimiawi dan konsumsi garam berlebihan. Pada hipertensi esensial, 
tekanan darah tidak normal lebih disebabkan oleh interaksi faktor diet, aktivitas, dan genetik.

Garam ( $\mathrm{NaCl})$ berperan penting dalam pemberian rasa dalam bentuk bumbu (seasoning) dan pengolahan makanan dan minuman. Garam memberi rasa (flavor), memperbaiki daya tahan, dan karakteristik makanan dan minuman. Keberadaan garam menimbulkan rasa lezat pangan karena efek rasa asinnya (salty taste). Mineral natrium $(\mathrm{Na})$ dan chlor $(\mathrm{Cl})$ pada garam adalah zat gizi mikro esensial bagi tubuh manusia, karena tidak diproduksi oleh tubuh melainkan harus mendapat asupan dari pangan. Asupan garam dalam jumlah cukup diperlukan tubuh untuk, antara lain, transmisi rangsangan syaraf dan kontraksi otot. Namun, asupan garam berlebih dalam jangka waktu tertentu, telah dibuktikan secara ilmiah ada hubungannya dengan penyakit jantung, tekanan darah tinggi, dan stroke.

Kebiasaan konsumsi pangan cepat dan siap saji (fast food), refined food, dan pangan awetan, meningkatkan asupan garam natrium (Na). Asupan garam berlebih dan pola makan tidak seimbang mengganggu keseimbangan kadar elektrolit darah $\left(\mathrm{Na}^{+}, \mathrm{K}^{+}, \mathrm{Mg}^{2+}\right.$, dan $\left.\mathrm{Ca}^{2+}\right)$. Sementara, faktor non pangan seperti stress dan atau tidak aktif beraktivitas (sedentary), serta faktor genetik berakibat lanjut pada gangguan kerja enzim renin-angiotensin, yang berakibat pada ketidakseimbangan tekanan darah.

Faktor penyebab lainnya, yaitu keterbatasan pengetahuan masyarakat tentang jenis mineral pengatur tekanan darah, sehingga pemahaman pengendalian hipertensi terbatas pada penurunan konsumsi garam natrium $(\mathrm{NaCl})$ saja. Selain itu, garam rendah $\mathrm{Na}$ dan tinggi mineral $\mathrm{Ca}, \mathrm{K}$,dan $\mathrm{Mg}$ belum tersedia di pasar

Pada kenyataannya, prevalensi penderita hipertensi, stroke, dan jantung semakin meningkat. Di dunia, diperkirakan pada tahun 2025, hipertensi pada orang dewasa meningkat 29 persen. ${ }^{1}$ Di Indonesia, laporan WHO di Jakarta tahun 2003 menunjukkan prevalensi hipertensi pada wanita sebanyak 12,1 persen. Sejumlah 25 persen orang dewasa mengalami hipertensi (tekanan darah $\geq 140 / 90 \mathrm{mmHg}$ ) dan sebanyak 50 persen orang dewasa berusia $>65$ tahun mengalami hipertensi. ${ }^{2}$
Beberapa solusi masalah hipertensi, khususnya ketidakseimbangan asupan mineral $\mathrm{Ca}, \mathrm{K}$, dan $\mathrm{Mg}$ dapat di atasi dengan tiga cara, yaitu 1) konsumsi suplemen mineral, 2) meningkatkan asupan mineral dari pangan sumber mineral pengatur tekanan darah tersebut, dan 3) fortifikasi dan substitusi mineral $\mathrm{Na}$ dengan mineral $\mathrm{Mg}, \mathrm{Ca}$, dan $\mathrm{K}$. Fortifikasi mineral iodium pada garam telah berhasil dilakukan pemerintah untuk pencegahan penyakit gondok. Namun kini, dengan semakin meningkatnya prevalensi hipertensi, upaya penyediaan garam rendah $\mathrm{Na}$, atau garam berisi mineral pengatur tekanan darah menjadi suatu kebutuhan penting. Jenis garam yang tersedia di pasar terbatas pada garam $\mathrm{NaCl}$ dan garam rendah natrium (garam lososa). Oleh karena itu, diperlukan jenis garam yang berisi empat jenis mineral pengatur tekanan darah ( $\mathrm{Na}, \mathrm{Ca}, \mathrm{K}$, dan $\mathrm{Mg}$ ) dalam jumlah seimbang. Formulasi jenis garam multimineral tersebut memerlukan aplikasi teknik substitusi mineral yang dilakukan pada studi ini.

Adapun tujuan studi ini adalah untuk formulasi garam multimineral (FGM) dengan teknik substitusi garam natrium (Na). Tujuan lainnya, adalah analisis mutu fisik dan mutu sensoris garam multimineral ( $\mathrm{Na}, \mathrm{Ca}, \mathrm{K}$, dan $\mathrm{Mg}$ ). Selanjutnya, studi ditujukan untuk menguji efek sehat penurunan tekanan darah penderita hipertensi yang dilakukan pada uji klinis.

\section{METODE PENELITIAN}

Studi eksperimental ini terdiri atas 3 tahapan, yaitu 1) formulasi garam multimineral (FGM), 2) uji mutu fisik dan sensoris formula FGM, dan 3) uji klinis pengaruh positif FGM. Kegiatan tahapan 1 dan 2 dilakukan di Laboratorium Kimia FMIPA Universitas Jember dan Laboratorium Pengolahan FTP Universitas Jember, tahun 2010-2011. Sementara uji klinis garam dilakukan pada masyarakat di Jember selama 30 hari.

Bahan utama yang digunakan untuk formulasi garam multimineral yaitu garam dasar $(\mathrm{NaCl})$ berasal dari P.T. GS. Garam lainnya yaitu garam mineral $\mathrm{KCl}, \mathrm{MgCl}_{2}, \mathrm{CaCl}_{2}, \mathrm{CaCO}_{3}$, $\mathrm{MgCO}_{3}$, dan $\mathrm{KIO}_{3}$ kategori food grade (EMerck). 
Tabel 1

Bentuk Garam Klorida dan Karbonat pada Formula Garam Multimineral (FGM)

\begin{tabular}{lccccccccc}
\hline \multirow{2}{*}{$\begin{array}{l}\text { Formula } \\
\text { Garam }\end{array}$} & \multicolumn{3}{c}{ Komposisi Garam Klorida dan Garam } & \multicolumn{5}{c}{ Formula Garam Multimineral (FGM) (\% AKG) } \\
\cline { 2 - 11 } & $\mathrm{NaCl}$ & $\mathrm{KCl}$ & $\mathrm{MgCO}_{3}$ & $\mathrm{CaCO}_{3}$ & $\mathrm{NaCl}$ & $\mathrm{KCl}$ & $\mathrm{MgCl}_{2}$ & $\mathrm{CaCl}_{2}$ & $\mathrm{KIO}_{3}$ \\
\hline FGM-1 & 60 & 20 & 10 & 10 & 94 & 10 & 18 & 14 & 53 \\
FGM-2 & 60 & 10 & 20 & 10 & 94 & 5 & 36 & 14 & 53 \\
FGM-3 & 60 & 10 & 10 & 20 & 94 & 5 & 18 & 29 & 53 \\
FGM-4 & 60 & 0 & 10 & 10 & 94 & 0 & 18 & 14 & 53 \\
FGM-5 & 60 & 0 & 20 & 10 & 94 & 0 & 36 & 14 & 53 \\
FGM-6 & 60 & 0 & 10 & 20 & 94 & 0 & 18 & 29 & 53 \\
FGM-7 & 60 & 20 & 0 & 10 & 94 & 10 & 0 & 14 & 53 \\
FGM-8 & 60 & 10 & 0 & 10 & 94 & 5 & 0 & 14 & 53 \\
FGM-9 & 60 & 10 & 0 & 20 & 94 & 5 & 0 & 29 & 53 \\
FGM-10 & 60 & 20 & 10 & 0 & 94 & 10 & 18 & 0 & 53 \\
FGM-11 & 60 & 10 & 20 & 0 & 94 & 5 & 36 & 0 & 53 \\
FGM-12 & 60 & 10 & 10 & 0 & 94 & 5 & 18 & 0 & 53 \\
FGM-13 & 60 & 0 & 0 & 10 & 94 & 0 & 0 & 14 & 53 \\
FGM-13 & 60 & 0 & 0 & 10 & 94 & 0 & 0 & 14 & 53 \\
FGM-14 & 60 & 0 & 0 & 20 & 94 & 0 & 0 & 29 & 53 \\
FGM-15 & 60 & 0 & 10 & 0 & 94 & 0 & 18 & 0 & 53 \\
FGM-16 & 60 & 0 & 20 & 0 & 94 & 0 & 36 & 0 & 53 \\
FGM-15 & 60 & 0 & 10 & 0 & 94 & 0 & 18 & 0 & 53 \\
FGM-17 & 60 & 20 & 0 & 0 & 94 & 10 & 0 & 0 & 53 \\
FGM-18 & 60 & 10 & 0 & 0 & 94 & 5 & 0 & 0 & 53 \\
\hline
\end{tabular}

Formulasi Garam Multimineral (MM). Garam MM yang diformulasi adalah garam rendah sodium $(\mathrm{Na})$ yang disubstitusi mineral pengatur tekanan darah, dengan kombinasi nisbah substitusi $\mathrm{Na}(40 \%)=\mathrm{Ca}: \mathrm{Mg}: \mathrm{K}=$ 10:20:10, sehingga diperoleh sebanyak 18 formula garam multimineral (FGM) (Tabel 1). Dengan demikian, FGM mengandung lima jenis mineral, yaitu sodium (Na), kalium (K), iodium $(\mathrm{J})$, magnesium $(\mathrm{Mg})$, dan kalsium (Ca). Formula dirumuskan dengan mempertimbangkan jumlah asupan lima mineral sesuai Anjuran Kecukupan Gizi (AKG), yaitu secara berturut-turut, $\mathrm{Na}=500 \mathrm{mg} / \mathrm{hr}, \mathrm{K}=2000$ $\mathrm{mg} / \mathrm{hr}, \mathrm{Mg}=280 \mathrm{mg} / \mathrm{hr}, \mathrm{Ca}=500 \mathrm{mg} / \mathrm{hr}$, dan $\mathrm{I}=150 \mu \mathrm{g} / \mathrm{hr} .{ }^{3}$ Formulasi dilakukan dengan teknik homogenasi kering (dry homogenation) semua bahan garam.

Pada uji kekeruhan digunakan formula garam mineral dalam dua bentuk, yaitu garam klorida dan garam karbonat. Uji kekeruhan dilakukan untuk menentukan bentuk garam yang aman klorida atau karbonat yang tidak berpengaruh terhadap mutu fisik dan kimawi garam saat pengolahan dan penentuan bentuk mineral aman. Uji kekeruhan dilakukan dengan cara melarutkan 1 gram garam MM dalam 100 $\mathrm{mL}$ air, lalu distirer selama 3 menit, kemudian diamati kekeruhan secara visual.

Uji Mutu FGM. ${ }^{4}$ Kadar air garam dianalisis dengan metode oven melalui penentuan kadar air awal, kadar air kesetimbangan, dan kadar air kritis. Tingkat kekeruhan dianalisis dengan metode Helige yaitu berdasarkan kemampuan absorptometrik yang ditunjukkan oleh nilai turbiditas. Kecerahan warna garam atau Intensitas warna dianalisis dengan metode colorimetri dengan sistem L"*a*b* (CIE Lab.Color Scale). Keragaman kristal garam ditentukan dengan teknik penyaringan dengan penyaring dengan ukuran mesh. Daya larut garam ditentukan dengan teknik penyaringan dan perhitungan berat endapan. Uji mutu sensoris FGM dilakukan terhadap rasa dan warna, sementara uji kesukaan dilakukan terhadap parameter rasa garam. Skala numerik yang digunakan adalah 1 sampai 5, 1 untuk kategori sangat suka, 2 untuk suka, 3 untuk agak suka, 4 untuk tidak suka, dan 5 untuk sangat tidak suka. 
Uji kesukaan dilakukan oleh panelis semi terlatih.

Uji klinis efek konsumsi FGM. Subjek uji FGM adalah individu penderita hipertensi ringan dengan nilai tekanan darah sistolik (TDS) $=160$ $200 \mathrm{~mm} \mathrm{Hg}$, diastolik (TDD) $=95-110 \mathrm{~mm} \mathrm{Hg}$, berusia 45-65 tahun, dan hidup dalam keluarga dengan pola konsumsi pangan yang relatif sama, dengan asupan 1900 Kalori. Hasil uji mutu sensoris tiga FGM berikut : FGM-1, FGM2, dan FGM-3, diujikan (dikonsumsi) ke subjek selama 30 hari. Kegiatan uji efek fisiologis, yang telah mendapakan persetujuan kelayakan dari Komisi Etik Penelitian Nasional ini (etical clearance. Nomor.040/PANEC/LPPM/2009), dirancang sebagai a double-blind randomized placebo-controlled parallel study. Garam FGM terpilih diujikan ke penderita hipertensi setelah dilakukan informed consent untuk mendapatkan persetujuan partisipasi subjek pada uji klinis. Pengukuran tekanan darah dilakukan pada sebelum (0 hari) dan sesudah pemberian garam-hipertensi (hari ke 31).

Analisis Data. Data karakteristik mutu ke tiga jenis garam FGM diolah secara deskriptif kuantitatif dan dibandingkan dengan mutu baku garam. Data uji mutu sensoris diolah dan disajikan secara deskriptif kuantaitatif dan kualitatif. Data hasil uji pengaruh konsumsi garan FGM terhadap tekanan darah penderita hipertensi dianalisis secara statistik uji Khai Kuadrat dan dilanjutkan dengan uji Kruskall Wallis.

Tabel 2

Hasil Uji Kelarutan dan Kekeruhan FGM Klorida dan Karbonat

\begin{tabular}{|c|c|c|c|c|c|c|c|c|c|c|}
\hline \multirow{2}{*}{$\begin{array}{l}\text { Formula } \\
\text { Garam }\end{array}$} & \multicolumn{4}{|c|}{ Komposisi (dalam \% w/w) } & \multicolumn{3}{|c|}{ Air Dingin } & \multicolumn{3}{|c|}{ Air Panas } \\
\hline & $\mathrm{NaCl}$ & $\mathrm{KCl}$ & $\mathrm{MgCO} 3$ & $\mathrm{CaCO} 3$ & $\mathrm{~L}$ & $\mathrm{~K}$ & $E$ & $\mathrm{~L}$ & $\mathrm{~K}$ & $E$ \\
\hline FGM-1 & 60 & 20 & 10 & 10 & - & + & + & - & + & + \\
\hline FGM-2 & 60 & 10 & 20 & 10 & - & + & + & - & + & + \\
\hline FGM-3 & 60 & 10 & 10 & 20 & - & + & + & - & + & + \\
\hline FGM-4 & 60 & 0 & 10 & 10 & - & + & + & - & + & + \\
\hline FGM-5 & 60 & 0 & 20 & 10 & - & + & + & - & + & + \\
\hline FGM-6 & 60 & 0 & 10 & 20 & - & + & + & - & + & + \\
\hline FGM-7 & 60 & 20 & 0 & 10 & - & + & + & - & + & + \\
\hline FGM-8 & 60 & 10 & 0 & 10 & - & + & + & - & + & + \\
\hline FGM-9 & 60 & 10 & 0 & 20 & - & + & + & - & + & + \\
\hline FGM-10 & 60 & 20 & 10 & 0 & - & + & + & - & + & + \\
\hline FGM-11 & 60 & 10 & 20 & 0 & - & + & + & - & + & + \\
\hline FGM-12 & 60 & 10 & 10 & 0 & - & + & + & - & + & + \\
\hline FGM-13 & 60 & 0 & 0 & 10 & - & + & + & - & + & + \\
\hline FGM-13 & 60 & 0 & 0 & 10 & - & + & + & - & + & + \\
\hline FGM-14 & 60 & 0 & 0 & 20 & - & + & + & - & + & + \\
\hline FGM-15 & 60 & 0 & 10 & 0 & - & + & + & - & + & + \\
\hline FGM-16 & 60 & 0 & 20 & 0 & - & + & + & - & + & + \\
\hline FGM-15 & 60 & 0 & 10 & 0 & - & + & + & - & + & + \\
\hline FGM-17 & 60 & 20 & 0 & 0 & + & - & - & + & - & - \\
\hline FGM-18 & 60 & 10 & 0 & 0 & + & - & - & + & - & _- \\
\hline
\end{tabular}

\section{HASIL}

\section{Kelarutan dan Kekeruhan Garam Klorida dan Karbonat FGM}

Hasil uji kekeruhan formula garam multimineral (FGM) dengan komposisi substitusi
40 persen garam $\mathrm{NaCl}$ dengan dua jenis bentuk garam (klorida dan karbonat) (Tabel 2) menunjukkan bahwa bentuk garam mineral yang tidak mempengaruhi warna FGM adalah garam klorida. Garam FGM yang tidak mengandung kedua jenis garam karbonat yaitu 
FGM-17 dan FGM-18 tidak menimbulkan kekeruhan saat garam larut dalam cairan dingin maupun panas.

\section{Kadar Elektrolit Unsur Mineral Formula Garam Multimineral}

Secara perhitungan, kadar elektrolit unsur mineral natrium $\left(\mathrm{Na}^{2+}\right)$, kalium $\left(\mathrm{K}^{+}\right)$, magnesium $\left(\mathrm{Mg}^{2+}\right)$, kalsium $\left(\mathrm{Ca}^{2+}\right)$, dan iodium (I) pada FGM disajikan pada Tabel 3. Asupan natrium ( $\mathrm{Na})$ dan iodium (I) yang akan diperoleh jika mengkonsumsi garam FGM-1, FGM-2, atau FGM-3 adalah sama yaitu 470 mg (94\% AKG) dan $48 \mu \mathrm{g}(32 \%$ AKG). Sebaliknya, asupan mineral $\mathrm{K}, \mathrm{Mg}$, dan $\mathrm{Ca}$ bervariasi sesuai formulanya. Asupan kalium (K) yang akan diperoleh jika mengkonsumsi FGM-1, sebesar $209 \mathrm{mg}$ (11\% AKG), FGM-2 dan FGM-3 masing-masing sebesar 6 persen AKG. Asupan magnesium (Mg) yang akan diperoleh jika mengkonsumsi FGM-1, dan FGM-3 sebesar 51 mg (18\% AKG), sementara FGM-2, sebesar $102 \mathrm{mg}$ (36 \%AKG). Asupan kalsium (Ca) yang akan diperoleh jika mengkonsumsi FGM-1, dan FGM-2 sebesar $72 \mathrm{mg}$ (15\% AKG), sementara FGM-3 sebesar $144 \mathrm{mg}$ (30\% AKG).

Tabel 3

Kadar Elektrolit Garam FGM/FGH

\begin{tabular}{lccccc}
\hline Formula Garam & \multicolumn{5}{c}{ Kadar elektrolit (perhitungan, $\mathrm{mg} / 2 \mathrm{~g}$ ) } \\
\cline { 2 - 6 } & $\mathrm{Na}^{2+}$ & $\mathrm{K}^{+}$ & $\mathrm{Mg}^{2+}$ & $\mathrm{Ca}^{2+}$ & $\mathrm{I}(\mathrm{ug})$ \\
\hline FGM-1 = FGH 6211 & 470 & 209 & 51 & 72 & 48 \\
FGM-2 = FGH6121 & 470 & 105 & 102 & 72 & 48 \\
FGM-3 = FGH6112 & 470 & 105 & 51 & 144 & 48 \\
FGM-4 = FGH 6011 & 470 & 0 & 51 & 72 & 48 \\
FGM-5 = FGH 6021 & 470 & 0 & 102 & 72 & 48 \\
FGM-6 = FGH 6012 & 470 & 0 & 51 & 72 & 48 \\
FGM-7 = FGH 6201 & 470 & 209 & 0 & 72 & 48 \\
FGM- 8= FGH 6101 & 470 & 105 & 0 & 72 & 48 \\
FGM-9 = FGH 6102 & 470 & 105 & 0 & 144 & 48 \\
FGM-10 = FGH 6210 & 470 & 209 & 51 & 0 & 48 \\
FGM-11 = FGH 6120 & 470 & 105 & 102 & 0 & 48 \\
FGM-12 = FGH 6110 & 470 & 105 & 51 & 0 & 48 \\
FGM-13 = FGH 6001 & 470 & 0 & 0 & 72 & 48 \\
FGM-14 = FGH 6002 & 470 & 0 & 0 & 144 & 48 \\
FGM-15 = FGH 6010 & 470 & 0 & 51 & 0 & 48 \\
FGM-16 = FGH 6020 & 470 & 0 & 102 & 0 & 48 \\
FGM -17 = FGH6200 & 470 & 209 & 0 & 0 & 48 \\
FGM-18= FGH 6100 & 470 & 105 & 0 & 0 & 48 \\
\hline
\end{tabular}

\section{Kadar Air Formula Garam Multimineral}

Kadar air garam merupakan indikator kritis penentuan umur simpan garam sehingga perlu ditentukan untuk menjamin mutu garam. Hasil uji kadar air garam FGM-1, FGM-2, dan FGM-3 menunjukkan bahwa rerata kadar air garam FGM tersebut sebesar 0,68 persen. Garam FGM-3 berkadar air 0,96 persen, FGM-2 berkadar air terendah $(0,83 \%)$, sedangkan FGM-1 berkadar air tertinggi $(1,22 \%)$.

\section{Mutu Fisik dan Tingkat Kesukaan FGM}

Hasil uji kesukaan warna (Tabel 4) menunjukkan bahwa garam FGM berwarna putih (whiteness $=72,4)$ dan cerah $(L=75,7)$, serta masih lebih disukai $(3,2)$ daripada garam kontrol ( $\mathrm{NaCl}: \mathrm{KCl}=60: 40)$. Tingkat kesukaan subjek terhadap warna FGM berkisar 2,6 - 4,2 (suka hingga tidak suka).

Garam FGM-6 (NaCl:KCl:MgCl:CaCl= 60:0:10:20) berwarna terputih $(78,7)$. Garam FGM yang paling disukai warnanya, adalah FGM-1 ( $\mathrm{NaCl}: \mathrm{KCl}: \mathrm{MgCl}: \mathrm{CaCl}=60: 20: 10: 10)$. Sebaliknya, warna FGM yang paling tidak disukai yaitu FGM-15 (NaCl:KCl:MgCl:CaCl= 60:0:10:0).

Nilai kesukaan rasa garam FGM berkisar 2,4-3,5 (suka hingga agak suka) dengan rerata nilai kesukaan sebesar 2,89. Garam FGM-2 ( $\mathrm{NaCl}: \mathrm{KCl}: \mathrm{MgCl}: \mathrm{CaCl}=60: 10: 20: 10$ ), kemudian 
FGM-3(60:10:10:20), dan FGM-5 (60:0:20:10), disukai rasanya $(=2,4)$. Rasa FGM lebih disukai daripada garam control ( $\mathrm{NaCl}: \mathrm{KCl}=60: 40)$.

Hasil uji Kruskal-Wallis Test menunjukkan bahwa tingkat kesukaan terhadap warna FGM1, FGM-2, dan FGM-3 ( $X^{2}=3,545$, Asymp.sig $0,170>a=0,05)$ tidak ada bedanya. Warna garam FGM yang paling disukai warnanya, yaitu FGM-3 (mean rank=33,17). Namun, tingkat kesukaan terhadap rasa $\mathrm{FGM}$ berbeda $\left(X^{2}=9,013\right.$, Asymp. sig $\left.0,011<a=0,05\right)$.

Tabel 4

Hasil Uji Mutu Fisik dan Kesukaan FGM/FGH

\begin{tabular}{lcccc}
\hline Formula Garam & Kecerahan $(\mathrm{L})$ & $\begin{array}{c}\text { Derajat Putih } \\
\text { Multimineral }\end{array}$ & & \multicolumn{2}{c}{ Uji Kesukaan } \\
\cline { 4 - 5 } & 73,0 & 70,1 & 2,6 & 3.0 \\
\hline FGM-1 = FGH 6211 & 74,6 & 71,4 & 2,9 & 2,4 \\
FGM-2 = FGH6121 & 77,2 & 74,0 & 2,7 & 2,4 \\
FGM-3 = FGH6112 & 73,1 & 69,6 & 3,2 & 3,0 \\
FGM-4 = FGH 6011 & 72,7 & 69,5 & 3,1 & 2,4 \\
FGM-5 = FGH 6021 & 78,7 & 74,2 & 3,2 & 2,7 \\
FGM-6 = FGH 6012 & 76,8 & 73,0 & 2,8 & 2,8 \\
FGM-7 = FGH 6201 & 76,9 & 73,9 & 3,1 & 3,1 \\
FGM- 8= FGH 6101 & 77,4 & 73,4 & 2,9 & 2,8 \\
FGM-9 = FGH 6102 & 73,6 & 71,1 & 2,7 & 3,0 \\
FGM-10 = FGH 6210 & 76,2 & 72,8 & 3,4 & 3,3 \\
FGM-11 = FGH 6120 & 76,8 & 72,9 & 3,1 & 2,9 \\
FGM-12 = FGH 6110 & 77,8 & 74,0 & 3,7 & 2,7 \\
FGM-13 = FGH 6001 & 76,3 & 73,4 & 3,9 & 2,5 \\
FGM-14 = FGH 6002 & 74,7 & 71,4 & 4,2 & 3,5 \\
FGM-15 = FGH 6010 & 76,1 & 73,8 & 4,0 & 3,2 \\
FGM-16 = FGH 6020 & 75,7 & 72,5 & 3,6 & 3,2 \\
FGM -17 = FGH6200 & 74,8 & 71,8 & 3,2 & 3,2 \\
FGM-18= FGH 6100 & 76.0 & 72,9 & 3,7 & 3,2 \\
KONTROL &
\end{tabular}

Keterangan: 1 = sangat suka, 2 = suka, 3=agak suka, 4= tidak suka, 5=sangat tidak suka

\section{Karakteristik Subjek Penderita Hipertensi}

Subjek hipertensi yang memenuhi syarat populasi sebanyak 51 orang, yang terdiri atas 34 perempuan dan 17 lelaki, berusia 35-75 tahun, dan sebagian besar, lebih dari 50 persen subjek garam hipertensi berumur antara 46-65 tahun. Hampir semua subjek terkategori status gizi baik, dengan nilai indeks massa tubuh (IMT) berkisar 25-27. Subjek melakukan aktivitas sehari-hari yang terkategori kegiatan ringan dan lebih dari sebagian (55\%) tidak rutin melakukan olah raga. Cukup baiknya bahwa sebagian besar subjek tidak merokok (87\%).

\section{Tekanan Darah Sistolik (TDS) dan Diastolik (TDS) Subjek Hipertensi}

Tekanan darah sistolik (TDS) subjek hipertensi sebelum konsumsi FGM menunjukkan, nilai rerata TDS, yaitu 167,10 $\mathrm{mmHg}$, dan sebaran nilai TDS subjek berkisar antara 130-240 mmHg, dengan sebaran terbanyak pada nilai TDS antara 150-190. Nilai TDS terendah sebelum perlakuan adalah 128 $\mathrm{mmHg}$ dan nilai TDS tertinggi sebelum perlakuan adalah $240 \mathrm{mmHg}$. Setelah konsumsi FGM, tekanan darah sitolik (TDS) sebagian besar (80\%) subjek penderita sebesar 160 $\mathrm{mmHg}$.

Nilai rerata TDS setelah konsumsi FGM, yaitu $164,86 \mathrm{mmHg}$, dengan nilai TDS terendah $=120 \mathrm{mmHg}$ dan TDS tertinggi $=250 \mathrm{mmHg}$. Gambar 1 memperlihatkan bahwa terjadi penurunan nilai rerata TDS dari 167,10 menjadi $164,86 \mathrm{mmHg}$, atau sedikit penurunan sebesar 1,3 persen. Demikian pula, pergeseran sebaran nilai TDS sebelum dan sesudah konsumsi FGM 
tidak besar, yaitu dari kisaran $128-240 \mathrm{mmHg}$ menjadi $<120-250 \mathrm{mmHg}$.

Tekanan Darah Diastolik (TDD) pada subjek penderita hipertensi sebelum konsumsi FGM, sebagian besar subjek memiliki tekanan darah diastolik $90 \mathrm{mmHg}$. Nilai rerata TDD sebesar $98,43 \mathrm{mmHg}$, dengan nilai TDD terendah $70 \mathrm{mmHg}$ dan nilai tertinggi 130 $\mathrm{mmHg}$.

Setelah konsumsi garam FGM, sebagian besar subjek memiliki tekanan darah diastolik sebesar $90 \mathrm{mmHg}$. Nilai rerata TDD sebesar $92,16 \mathrm{mmHg}$, dengan nilai terendah TDD $=60$ $\mathrm{mmHg}$ dan nilai tertinggi TDD $=130 \mathrm{mmHg}$.

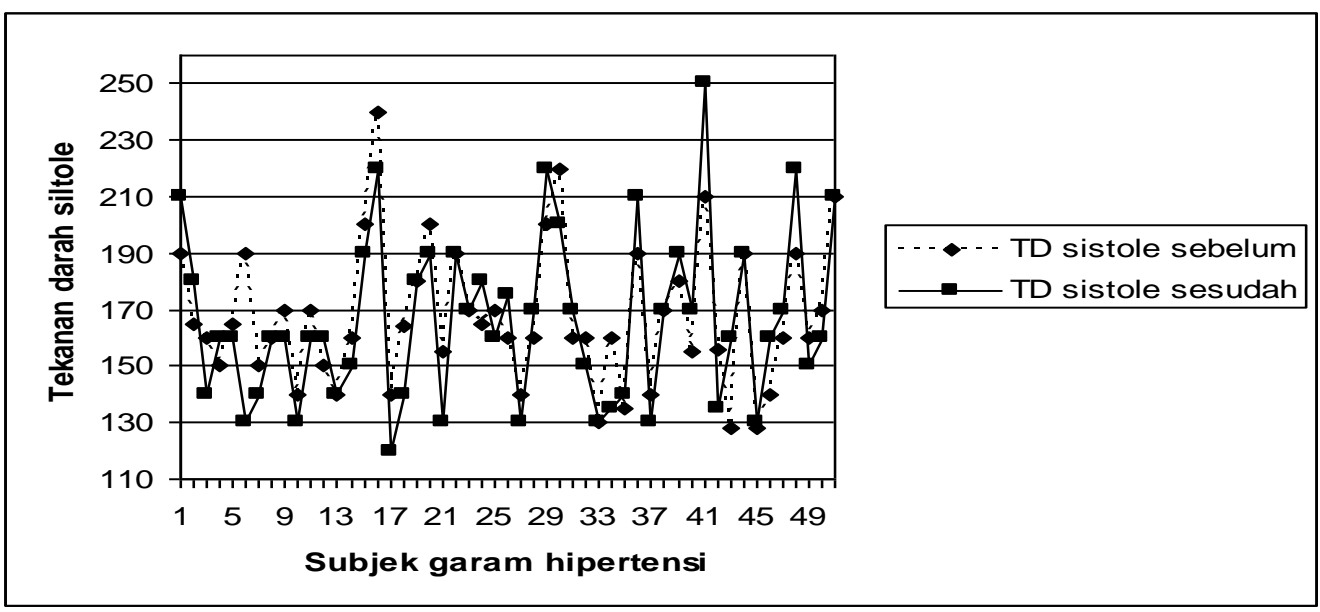

Gambar 1

Tekanan Darah Sistolik (TDS) Subjek Penderita Sebelum dan Sesudah Konsumsi Garam Hipertensi

Sebaran nilai TDD sebelum konsumsi garam GH sekitar $80-128 \mathrm{mmHg}$, lebih tinggi daripada sebaran nilai TDD setelah konsumsi, yaitu sekitar 78 - $108 \mathrm{mmHg}$ (Gambar 2). Demikian halnya, nilai TDD terendah setelah konsumsi $\mathrm{GH}$ yaitu $60 \mathrm{mmHg}$, lebih rendah dari nilai TDD terendah sebelum konsumsi garam $\mathrm{GH}$ yaitu $70 \mathrm{mmHg}$. Nilai rerata TDD setelah konsumsi garam $\mathrm{GH}$ sebesar $92,16 \mathrm{mmHg}$ lebih rendah dibandingkan nilai TDD sebelum konsumsi garam $\mathrm{GH}$ yaitu dibandingkan 98,43 $\mathrm{mmHg}$.

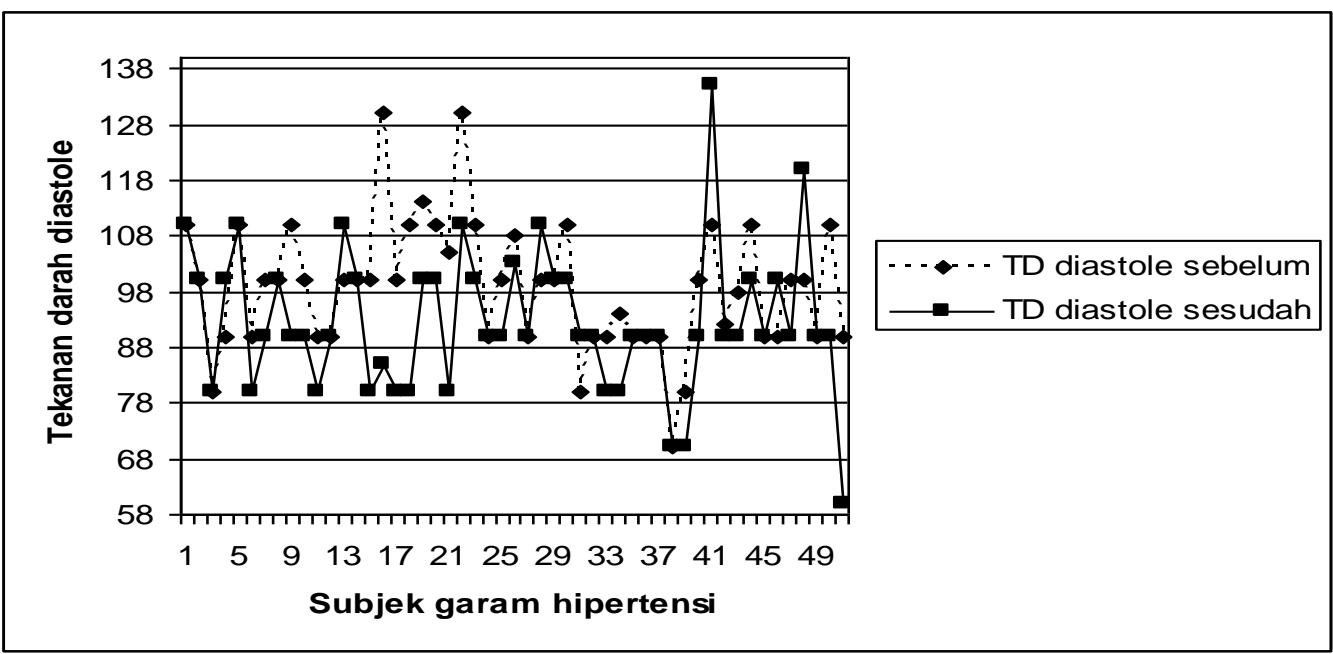

Gambar 2

Tekanan Darah Diastolik (TDD) Subjek Penderita Sebelum dan Sesudah Konsumsi Garam FGM

Hasil uji statistik dengan Khai Kuadrat dan uji Kruskall-Wallis sampel berpasangan data tekanan darah sistolik (TDS) membuktikan bahwa ada pengaruh konsumsi garam FGM 
sebanyak $2000 \mathrm{mg}$ x 3 kali makan dalam sehari terhadap tekanan darah subjek $\left(x^{2}=27,381\right.$ dengan Asymp.sig 0,000< $a=0,05$ ). Adapun formula yang paling berpengaruh menurunkan TDS, yaitu FGM-1 (mean rank tertinggi= 56,10). Hasil Uji statistik tersebut juga menunjukkan ada pengaruh nyata konsumsi garam FGM terhadap TDD subjek $\left(X^{2}=38,483\right.$ dengan nilai Asymp.sig $0,000<a=0,05$ ). Adapun formula yang paling berpengaruh menurunkan tekanan darah diastole adalah FGM-1 (mean rank tertinggi $=59,46$ ). Selanjutnya, hasil uji statistik uji Kruskall Wallis sampel berpasangan menunjukkan bahwa terdapat perbedaan nyata antara nilai TDD dan TDS sebelum dan sesudah konsumsi garam FGM.

\section{BAHASAN}

\section{Bentuk Garam Klorida Terpilih untuk Formula Garam Multimineral (FGM)}

Kelarutan garam menggambarkan tingkat larutnya garam multimineral dalam air dingin dan air panas. Kelarutan garam yang sempurna dalam air dingin dan panas sangat penting sehingga garam dapat digunakan dalam pengolahan pangan pada kondisi panas dan dingin. Kelarutan dan kekeruhan mempengaruhi tingkat kejernihan garam dalam larutan. Hasil uji kelarutan dan kekeruhan FGM dengan dua bentuk garam klorida dan karbonat pada Tabel 2 menunjukkan bahwa kedua garam FGM tersebut bersifat larut sempurna dalam air dingin. Garam klorida bersifat larut dalam air dan tidak menimbulkan kekeruhan. Garam karbonat juga bersifat larut dalam air, namun menimbulkan kekeruhan. Oleh karenanya, selanjutnya dalam formulasi garam multimineral (FGM) menggunakan bentuk garam klorida yaitu $\mathrm{NaCl}, \mathrm{KCl}, \mathrm{MgCl}$, dan $\mathrm{CaCl}$.

Penambahan jenis dan bentuk garam pada saat pangan dimasak berpengaruh terhadap ketersediaan mineral dalam garam. ${ }^{5}$ Sebagai anion penerima elektron, mineral $\mathrm{Cl}$ siap bergabung dengan unsur mineral lainnya, seperti $\mathrm{Na}, \mathrm{K}, \mathrm{Mg}$, dan $\mathrm{Ca}$ membentuk garam klorida. ${ }^{7}$

\section{Mutu Gizi Formula Garam Multimineral (FGM)}

Mutu gizi FGM pada studi ini dinilai dari kadar mineral pengatur tekanan darah dan kadar airnya. Konsumsi FGM memasok asupan mineral $\mathrm{Na}, \mathrm{K}, \mathrm{Mg}, \mathrm{Ca}$, dan I ke dalam tubuh dalam jumlah (\%AKG) berbeda. Perhitungan kadar elektrolit unsur mineral FGM dapat menggambarkan prakiraan jumlah asupan mineral yang diperoleh dari konsumsi garam tersebut. Hal tersebut dapat terjadi karena ketersediaan mineral tidak mudah terganggu oleh proses pengolahan, seperti panas, dan pengadukan pada proses formulasi garam tersebut. Selain itu, tidak terdapat senyawa organik yang dapat mengganggu ketersediaan mineral. ${ }^{7}$

Di dalam tubuh, anion utama ekstraselulerklor $(\mathrm{Cl})$, bersama dengan kation ektraseluler natrium $\left(\mathrm{Na}^{+}\right)$, dan kation intraseluler kalium $\left(\mathrm{K}^{+}\right)$ berfungsi dalam pemeliharaan tekanan osmotik dan regulasi keseimbangan asam -basa dan kation-anion, metabolisme air, pengambilan zat gizi, rangsangan syaraf, Mineral $\mathrm{Cl}$ berperan penting dalam pencernaan protein dan aktivasi amylase usus.

Mineral $\mathrm{Na}$ dan $\mathrm{Cl}$ penting dalam pemeliharaan hubungan volume normal cairan dan tekanan osmotic, pengontrolan jalur zat gizi menuju sel dan pengeluaran sisanya. Mineral $\mathrm{Na}$ berperan utama dalam transmisi rangsangan syaraf dan pemeliharaan kontraksi otot dan jantung. Mineral magnesium (Mg) sebagai kation cairan intraseluler terbanyak kedua setelah $\mathrm{K}$ berperan penting dalam hampir semua fungsi tubuh, seperti metabolisme karbohidrat, protein, dan lemak, serta respirasi seluler, imunitas, kontraksi otot, kelangsungan sel darah merah, dan dan metabolisme mineral $\mathrm{Na}$ dan $\mathrm{K}$. Kation Mg merupakan komponen aktif beberapa system enzim seperti kinase, karboksilase, dan transketolase.

Mineral $\mathrm{K}$ penting dalam transportasi oksigen dan karbondioksida via darah, dan pengendalian dalam pengaturan detak jantung dan penekanan debaran jantung. Mineral $\mathrm{Ca}$ penting dalam pembekuan darah normal karena $\mathrm{Ca}+$ diperlukan untuk merubah protrombin menjadi thrombin, yang akan bereaksi dengan fibrinogen membentuk pembekuan darah. Selain itu, $\mathrm{Ca}$ juga diperlukan dalam fungsi jantung, dan bersama $\mathrm{Na}^{+}, \mathrm{K}^{+}$, dalam regulasi detak jantung. Keseimbangan ion $\mathrm{Na}^{+}, \mathrm{K}^{+}, \mathrm{Mg}^{+}$, dan $\mathrm{Ca}^{+}$berpengaruh terhadap fungsi kapiler dan sel, serta kepekaan rangsangan syaraf dan otot.

Kadar air garam mempengaruhi mutu garam, terutama jika disimpan dalam waktu 
lama. Garam yang mengandung kadar air tinggi, di atas 3 persen mendukung pertumbuhan jamur. Pada studi ini dilakukan uji mikrobiologis untuk identifikasi mikroba dan jamur pada garam.

Hasil uji menunjukkan bahwa kandungan mikroba pada semua formula garam adalah negative. Sementara, pada garam dengan kadar air tinggi (di atas 3\%) terdapat jamur yang dapat menurunkan mutu garam.

\section{Mutu Sensoris Formula Garam Multimineral (FGM)}

Substitusi 40 persen natrium dengan mineral kalium $(\mathrm{K})$, magnesium $(\mathrm{Mg})$, dan kalsium $(\mathrm{Ca})$ diupayakan tidak berpengaruh terhadap warna dan rasa garam FGM. Penambahan unsur kalium memang berpengaruh terhadap rasa garam, karena $\mathrm{K}$ berasa pahit. Namun dengan kadar $\leq 40$ persen tidak terlalu berpengaruh terhadap rasa garam multimineral. Data hasil uji Kruskal-Wallis Test menunjukkan substitusi $\mathrm{Na}$ dengan mineral $\mathrm{Mg}$ dan $\mathrm{Ca}$ menyebabkan perbedaan kesukaan terhadap rasa garam FGM. Formula garam FGM yang paling disukai rasanya, yaitu FGM-2 ( $\mathrm{NaCl}: \mathrm{KCl}: \mathrm{MgCl}: \mathrm{CaCl}=60: 10: 20: 10$ ) (mean rank=29,21).

\section{Karakteristik Penderita Hipertensi}

Hipertensi adalah kondisi gangguan tekanan darah, yang berperan sebagai salah satu pencetus penyakit degeneratif, sehingga hipertensi lebih banyak ditemukan pada golongan dewasa dan lanjut usia. ${ }^{8}$ Memang umur merupakan salah satu faktor resiko hipertensi. Sebagaimana diketahui bahwa semakin bertambah umur, akan disertai dengan gejala ketuaan, berupa rambut rontok, gigi tanggal, kulit berkeriput, dan daya adaptasi serta kelenturan tubuh semakin berkurang, dan elastisitas pembuluh darah berkurang secara bertahap dengan bertambahnya usia. ${ }^{9}$ Subjek hipertensi pada studi ini berusia 45-65 tahun sehingga memungkinkan mengalami penurunan elastisitas pembuluh darah menimbulkan sehingga terjadi gangguan aliran darah, termasuk gangguan tekanan darah.

Beberapa hasil penelitian menunjukkan adanya hubungan antara berat badan dan hipertensi. Bila berat badan meningkat di atas nilai ideal maka resiko hipertensi juga meningkat. Selain itu, dibuktikan bahwa penurunan berat badan dan pengaturan berat badan merupakan pengobatan yang efektif untuk hipertensi. Bila berat badan menurun, maka volume darah total juga berkurang, hormon yang berkaitan dengan tekanan darah berubah, dan tekanan darah berkurang. ${ }^{10,11}$ Pada studi ini berat badan subjek hipertensi terkategori baik karena nilai indeks massa tubuh (IMT) berkisar 25-27, namun tidak melakukan olah raga rutin. Kegiatan olahraga selama 30 hingga 45 menit setiap hari selama lima hari dalam seminggu cukup untuk menurunkan hipertensi. Subjek hipertensi tidak merokok, namun perlu diketahui bahwa walau merokok tidak ada kaitan dengan timbulnya tekanan darah tinggi, merokok meningkatkan resiko komplikasi lain seperti penyakit jantung dan stroke pada penderita hipertensi.

\section{Efek Konsumsi FGM Terhadap Tekanan Darah Penderita Hipertensi}

Tekanan darah adalah besarnya gaya yang digunakan oleh darah pada setiap satuan luas daerah dinding pembuluh darah. Secara umum, tekanan darah dinyatakan dalam dua komponen, yaitu tekanan darah sistolik (TDS) dan diastolik (TDD). Tekanan sistolik adalah tekanan darah tertinggi yang dicapai pada saat jantung memompa darah. Sementara, tekanan darah diastolik tekanan darah pada saat jantung terisi darah di antara dua kali denyut jantung. Menurut WHO dalam guidelines tahun 1999, tekanan darah normal adalah $135 / 85 \mathrm{mmHg}$, sedangkan bila lebih dari $140 / 90 \mathrm{mmHg}$ disebut hipertensi. Secara sederhana seseorang menderita hipertensi jika tekanan darah sistolik (TDS) di atas $140 \mathrm{mmHg}$ dan tekanan diastolik (TDD) lebih besar dari $90 \mathrm{mmHg} .12$ Keadaan hipertensi diklasifikasi dalam 3 kategori, yaitu 1) hipertensi ringan (mild) jika TDD $=90-110,2$ ) hipertensi sedang (moderate )jika TDD $=110-$ 130, dan 3) hipertensi berat (severe) jika TDD $>130$. Pada studi ini, rerata nilai TDS/TDD adalah 167,10/98,43 mm/Hg, terkategori hipertensi ringan. Sebagian besar subjek terkategori hipertensi ringan.

Studi ini membuktikan bahwa konsumsi FGM sebanyak $2000 \mathrm{mg} \times 3$ kali makan dalam sehari $(6000 \mathrm{mg})$ dapat menurunkan tekanan darah sistolik (TDS) dan tekanan darah diastolik (TDD). Penurunan TDS dan TDD yang nyata tersebut dapat disebabkan oleh respons terhadap asupan kombinasi mineral $\mathrm{Na}, \mathrm{K}, \mathrm{Mg}$, 
dan $\mathrm{Ca}$, yang memang berfungsi dalam pengaturan tekanan darah. Penurunan tekanan darah yang tipis tersebut dapat disebabkan karena subjek berstatus hipertensi sedang sehingga respons penurunan tidak terlalu tinggi dibandingkan jika subjek dengan status hipertensi berat.

Nilai TDD digunakan sebagai indikator pada klasifikasi tingkat keadaan hipertensi karena nilai TDD relatif stabil dibandingkan dengan nilai TDS. Jika terjadi penurunan atau peningkatan nilai TDD yang sangat nyata, mengindikasikan respons yang nyata terhadap asupan pangan atau faktor resiko hipertensi lainnya. Dengan demikian, dapat dinyatakan bahwa konsumsi FGM sebanyak $2000 \mathrm{mg} \times 3$ kali makan dalam sehari selama 30 hari mampu menurunkan tekanan darah penderita hipertensi ringan.

\section{SIMPULAN DAN SARAN}

\section{Simpulan}

Formula garam multimineral (FGM) dengan kombinasi nisbah komposisi substitusi $\mathrm{Na}(40 \%)$ dengan mineral pengatur tekanan darah $\mathrm{K}: \mathrm{Ca}$ : Mg: I untuk FGM-1, FGM-2, dan FGM-3 masih disukai rasanya (nilai rerata $=2,6$ ) dan warnanya (nilai rerata $=2.7$ ). Garam FGM berkadar air di bawah 1 persen (FGM-3=0,96\% dan FGM$2=0,83 \%$ ), dan di atas 1 persen ( $F G M-1=1,22$ $\%$ ). Konsumsi garam FGM sebanyak $2000 \mathrm{mg} x$ 3 kali makan dalam sehari $(6000 \mathrm{mg})$ selama 30 hari berpengaruh nyata terhadap tekanan darah Sistolik (TDS) subjek ( $X^{2}=27,381$ dengan Asymp.sig $0,000<a=0,05$ ) dan tekanan darah diastolik (TDD) penderita hipertensi ringan $\left(X^{2}=38,483\right.$ dengan nilai Asymp.sig $0,000<a=$ $0,05)$. Garam multimineral formula FGM-1 dengan formulasi $\mathrm{NaCl}: \mathrm{KCl}: \mathrm{MgCl}: \mathrm{CaCl}=$ 60:20:10:10, diberikan sebanyak 3 × 2000 $\mathrm{mg} /$ hari paling berpengaruh menurunkan TDS (mean rank tertinggi $=56,10$ ), dan juga TDD (mean rank tertinggi $=59,46$ ) penderita hipertensi ringan.

\section{Saran}

Penelitian ini dapat dilanjutkan dengan menggunakan indikator fungsi kerja sistem enzim yang mengatur tekanan darah, seperti Renin Agiotensin, dan pengontrolan ketat asupan energi dan zat gizi yang baku pada penyandang hipertensi di rumah uji.

\section{RUJUKAN}

1. Kearney PM. Global Burden of Hypertentions. Lancet. 2005;365:(9455): 217-23.

2. World Health Organization .WHO/ISH Guidelines. J Hypertens. 2003; 21:198392.

3. Fregly MJ. Natrium dan Kalium. Dalam: Olson RE, Broquist HP, Darby WJ, Kolbye AC, dan Stalvey RM (eds).Pengetahuan Gizi Mutakhir: Mineral. Jakarta: PT Gramedia, 1988.

4. Tejasari. Analisis Nilai Gizi Pangan. Jember: Fakultas Teknologi Pertanian, 2010.

5. Tejasari. Nilai Gizi Pangan. Yogyakarta : CV Graha IImu, 2005.

6. McDowell LR. Minerals in Animal and Human Nutrition. Boston: Academic Press,Inc., 1992.

7. Clydesdale FM. Mineral Interactions in Food. In: Bodwell CE, and Erdman JW (eds). Nutrient Interactions. New York: Marcel Dekker, Inc. 1988.

8. Bustan MN. Epidemiologi Penyakit Tidak Menular. Jakarta : Rineka Cipta, 2000.

9. Simamora SJ. Pedoman Hidup Sehat. Bandung : CV Pionir Jaya, 1996.

10. Diehl H. Waspadai Diabetes, Kolesterol, Hipertensi.. Bandung : Indonesia Publishing House, 1996.

11. Gunawan L. Hipertensi Tekanan Darah Tinggi. Jakarta: Kanisius. 2005.

12. Soenardi T, dan Soetardjo S. Hidangan Sehat untuk Penderita Hipertensi. Jakarta: PT. Gramedia, 2005. 
